Article

\title{
Roadmapping the Transition to Water Resource Recovery Facilities: The Two Demonstration Case Studies of Corleone and Marineo (Italy)
}

\author{
Giorgio Mannina ${ }^{1}{ }^{*}$, Luigi Badalucco ${ }^{2} \mathbb{D}$, Lorenzo Barbara ${ }^{1}$, Alida Cosenza ${ }^{1}$, Daniele Di Trapani ${ }^{1}$ (D), \\ Vito Armando Laudicina ${ }^{2}$ D , Sofia Maria Muscarella ${ }^{2}$ and Dario Presti ${ }^{1}$ (D)
}

1 Department of Engineering, University of Palermo, Viale delle Scienze, 90128 Palermo, Italy; Lorenzo.Barbara@unipa.it (L.B.); alida.cosenza@unipa.it (A.C.); daniele.ditrapani@unipa.it (D.D.T.); Dario.Presti@unipa.it (D.P.)

2 Department of Agricultural, Food and Forest Science, University of Palermo, Viale delle Scienze, 90128 Palermo, Italy; Luigi.Badalucco@unipa.it (L.B.); vitoarmando.laudicina@unipa.it (V.A.L.); sofiamaria.muscarella@unipa.it (S.M.M.)

* Correspondence: giorgio.mannina@unipa.it; Tel.: +39-091-2389-6556

check for

updates

Citation: Mannina, G.; Badalucco, L.; Barbara, L.; Cosenza, A.; Di Trapani, D.; Laudicina, V.A.; Muscarella, S.M.; Presti, D. Roadmapping the Transition to Water Resource Recovery Facilities: The Two Demonstration Case Studies of Corleone and Marineo (Italy). Water 2022, 14, 156. https://doi.org/ $10.3390 / w 14020156$

Academic Editor: Marisa Almeida

Received: 2 December 2021

Accepted: 31 December 2021

Published: 7 January 2022

Publisher's Note: MDPI stays neutral with regard to jurisdictional claims in published maps and institutional affiliations.

Copyright: (C) 2022 by the authors. Licensee MDPI, Basel, Switzerland. This article is an open access article distributed under the terms and conditions of the Creative Commons Attribution (CC BY) license (https:// creativecommons.org/licenses/by/ $4.0 /)$.

\begin{abstract}
The current exploitation of freshwater, as well as the significant increase in sewage sludge production from wastewater treatment plants (WWTPs), represent nowadays a critical issue for the implementation of sustainable development consistent with the circular economy concept. There is an urgent need to rethink the concept of WWTPs from the conventional approach consisting in pollutant removal plants to water resource recovery facilities (WRRFs). The aim of this paper is to provide an overview of the demonstration case studies at the Marineo and Corleone WRRFs in Sicily (IT), with the final aim showing the effectiveness of the resources recovery systems, as well as the importance of plant optimization to reduce greenhouse gas (GHG) emissions from WRRFs. This study is part of the H2020 European Project "Achieving wider uptake of water-smart solutions-WiderUptake", which final aim is to demonstrate the water-smart solution feasibility in the wastewater sector. The main project goal is to overcome the existing barriers that hamper the transition to circularity through the implementation of a governance analysis tool. The preliminary actions in the two demonstration cases are first presented, while, subsequently, the water-smart solutions to be implemented are thoroughly described, highlighting their roles in the transition process. The achieved preliminary results underlined the significant potential of WRRF application, a great chance to demonstrate the feasibility of innovative solutions in the wastewater sector to overcome the existing social, administrative and technical barriers.
\end{abstract}

Keywords: circular economy; wastewater treatment; water resource

\section{Introduction}

Nowadays, the exploitation of freshwater sources and the consistent expansion in the sewage sludge generation from wastewater treatment plants (WWTP) are significant ecological concerns and represent a challenge for sustainable growth [1]. These, along with other issues, such as greenhouse gas (GHG) emissions, energy efficiency, carbon footprint, emerging pollutants and the usage of chemicals, are being prioritized in wastewater management [2]. The scarcity of resources and sustainability goals are the driving major global changes in the wastewater industry. By applying the concept of circular economy and resource recovery to wastewater management systems, wastewater can be considered as a renewable resource from which water; energy and materials (e.g., nutrients, biopolymers and cellulose) can be recovered [3]. Wastewater treatment is becoming a key platform for paving the way towards sociotechnical developments that focus on the global production system transformation from a linear economy model to a circular one [3-5]. In a circular 
economy vision, the resources lost with waste streams (treated water, sludge and nutrients) can be recovered/reused, thus reducing the adoption of resources coming from the primary sources [6-8]. The combination of traditional wastewater treatment technologies and a new water-smart model that focuses on resource recovery is leading to a new way of perceiving wastewater treatment facilities. Indeed, the new paradigm is the conversion from wastewater treatment plants to water resource recovery facilities (WRRF) [9-11]. It is assumed that a WRRF (also known as "wastewater biorefinery" or "water resource factory") applies innovative technologies to operate at the intersection of wastewater treatment and biotechnological processes. In fact, it mainly exploits the activity of biological agents to extract valuable products while, at the same time, treating wastewater $[12,13]$.

Recently, the scientific community has increasingly paid attention to the establishment of technical solutions for the water sector based on circular economy, promoting the implementation of large-scale innovations allowing the paradigm shift from WWTPs to WRRFs [9]. However, implementing a resource recovery-oriented process is challenging due to, among others, high-cost investments [14]. As more and more resource recovery technologies are available, the WWTP design is no longer a simple technical problem but a complex problem that requires an integrated approach to make effective decisions [15]. Indeed, in addition to the technical vulnerabilities that apply to many arising emerging resource recovery technologies, different nontechnological bottlenecks might hamper the fruitful application of such innovations in the wastewater treatment sector [16].

The barriers hindering the transition to the WRRF paradigm are indeed also of economic, regulatory, social and educational, logistic/organizational and administrative character $[8,13,17]$. New and better models for interdisciplinary cooperation are required to keep away from the circumstances where policies, incentives and guidelines in different areas (e.g., energy, health and agriculture) may preclude or prevent the transformation of the industry based on wastewater resources.

There is, hence, an urgent need to further demonstrate and develop solutions for the new paradigm of wastewater treatment that are not only technological but also of different features, like innovative business models, governance and stakeholder commitment plans and educational programs focusing both on wastewater professionals and citizens. However, to implement the new paradigm, the potential in terms of resource recovery of the existing plant has to be known. In this light, this paper presents demonstration case studies of the Marineo and Corleone WRRFs, which aim to show the effectiveness of resources recovery systems and importance of plant optimization to reduce the plant carbon footprint. The activities presented here are part of the H2020 European Project "Achieving wider uptake of water-smart solutions-Wider-Uptake" [1].

\section{Sicilian Case Studies}

The WWTPs of Corleone and Marineo

The Corleone WWTP was designed for a daily flow rate of $3700 \mathrm{~m}^{3}$ day $^{-1}$ corresponding to 12,000 inhabitant equivalents. The Corleone WWTP is a typical conventional activated sludge (CAS) process with a pretreatment stage (sieving and degritting) followed by two aerobic biological reactors with surface aeration and three final clarifiers. In detail, each aerobic reactor is characterized by a square shaped horizontal section with a length of $11 \mathrm{~m}$ and a water level of $3.2 \mathrm{~m}$, corresponding to a net mixed liquor volume close to $390 \mathrm{~m}^{3}$. The WWTP has three identical final clarifiers, each characterized by a 12-m diameter and height of $1.75 \mathrm{~m}$ corresponding to a volume close to $200 \mathrm{~m}^{3}$. After the final settling, there is a disinfection unit with sodium hypochlorite before the final effluent discharge, currently into a nearby river. The WWTP also incorporates membrane modules for the final effluent filtration and a distribution network for water reuse (irrigation) in local agriculture and green urban areas (i.e., green gardens). The sludge line consists of two aerobic digesters, each with a volume close to $165 \mathrm{~m}^{3}$, and eight drying beds, with a horizontal surface equal to $40 \mathrm{~m}^{2}$. In Figure 1a, a panoramic view of the Corleone WWTP is reported. 

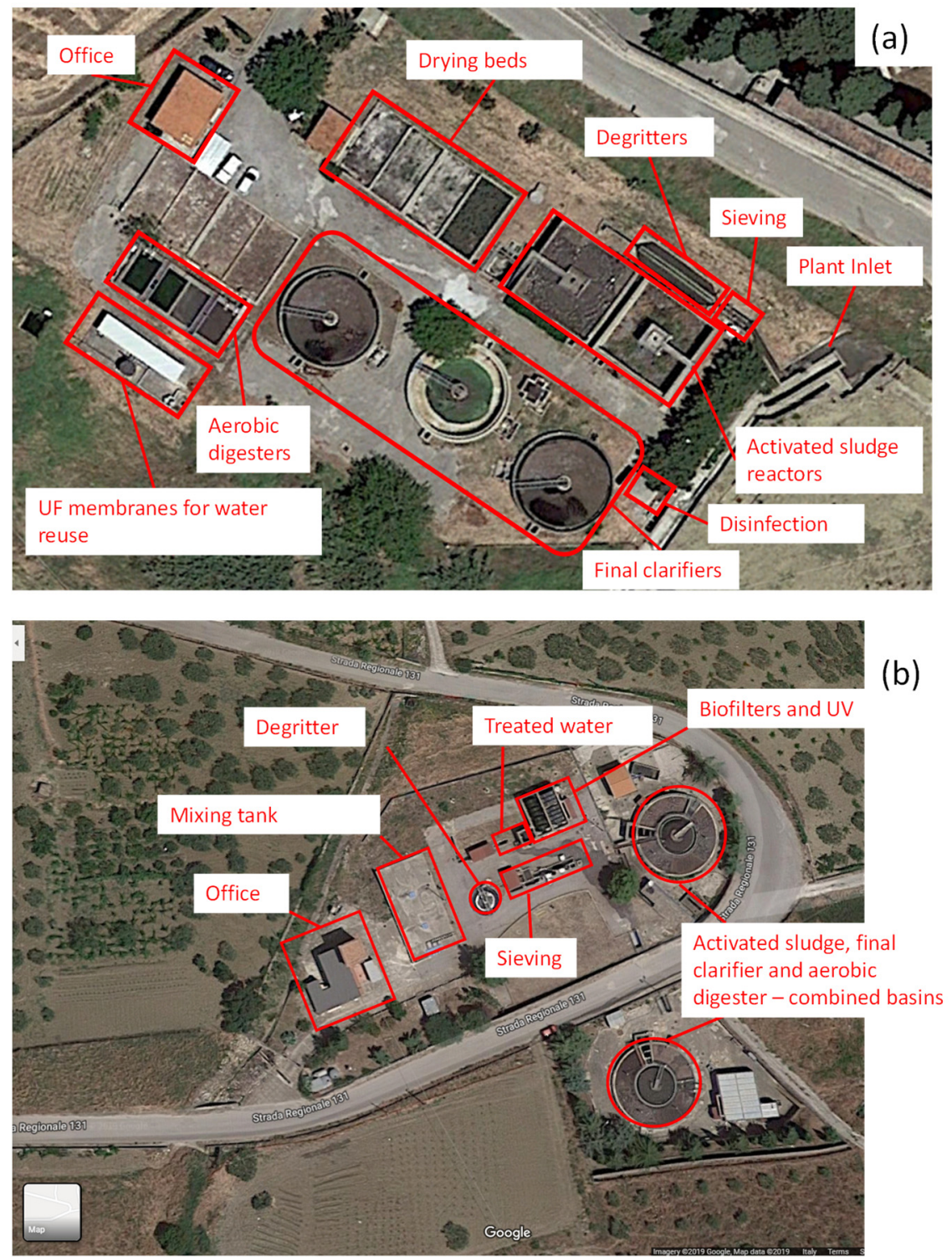

Figure 1. Panoramic view of the Corleone (a) and Marineo (b) WWTPs (source https: / / earth.google. com/web/ accessed on 20 July 2020).

The Marineo WWTP was designed for a daily flow rate of $2160 \mathrm{~m}^{3}$ day $^{-1}$ corresponding to 7000 inhabitant equivalents. After a pretreatment stage (screening, degritting, primary clarification and equalization), the plant is characterized by a CAS layout (with two identical combined basins) followed by a surface filtration unit and UV disinfection. Each combined basin incorporates an activated sludge reactor with net volume of $300 \mathrm{~m}^{3}$, a secondary clarifier characterized by a volume of $200 \mathrm{~m}^{3}$ and a horizontal surface of $540 \mathrm{~m}^{2}$, one aerobic digester with a volume of $250 \mathrm{~m}^{3}$. An irrigation network has been scheduled but not realized so far; therefore, at present, the WWTP effluent is discharged into a nearby river. Figure $1 \mathrm{~b}$ shows a panoramic view of the Marineo WWTP.

In Table 1, the influent and effluent values for the main parameters (average values) for both plants are shown. 
Table 1. Inlet and outlet average values of the main quality parameters for the Corleone and Marineo WWTPs.

\begin{tabular}{cccccc}
\hline \multicolumn{2}{c}{ WWTP } & \multicolumn{2}{c}{ Corleone } & \multicolumn{2}{c}{ Marineo } \\
\hline & Units & Influent & Effluent & Influent & Effluent \\
\hline TSS & $\left(\mathrm{mg} \mathrm{L}^{-1}\right)$ & 122.54 & 15.18 & 283 & 32.8 \\
$\mathrm{BOD}_{5}$ & $\left(\mathrm{mg} \mathrm{L}^{-1}\right)$ & 144.17 & 19.43 & 278 & 19.38 \\
$\mathrm{COD}$ & $\left(\mathrm{mg} \mathrm{L}^{-1}\right)$ & 239.76 & 33.31 & 565.5 & 42.5 \\
$\mathrm{TP}$ & $\left(\mathrm{mg} \mathrm{L}^{-1}\right)$ & 3.58 & n.a. & 12.73 & n.a. \\
$\mathrm{NH}_{4}{ }^{+}$ & $\left(\mathrm{mg} \mathrm{L}^{-1}\right)$ & 20.38 & 11.54 & 24.3 & 3.1 \\
$\mathrm{NO}_{2}^{-}$ & $\left(\mathrm{mg} \mathrm{L}^{-1}\right)$ & n.a. & 0.26 & n.a. & 1.03 \\
$\mathrm{NO}_{3}^{-}$ & $\left(\mathrm{mg} \mathrm{L}^{-1}\right)$ & n.a. & 2.29 & n.a. & 17.99 \\
\hline
\end{tabular}

\section{The Role of Wider-Uptake Project}

\subsection{Corleone}

In the context of Wider-Uptake Project, the Corleone WWTP is devoted to water and sludge reuse in agriculture, the minimization of sludge production and, overall, plant optimization in terms of energy consumption and GHG emissions.

The current main wastewater treatment line is being upgraded with an anaerobic sludge reactor inserted in the activated sludge recycling line according to the oxic-settlinganoxic/anaerobic (OSA) process configuration (Figure 2). Indeed, the CAS-OSA system is a technologically simple and economically sustainable solution designed to reduce the production of waste activated sludge compared to the CAS system [18].

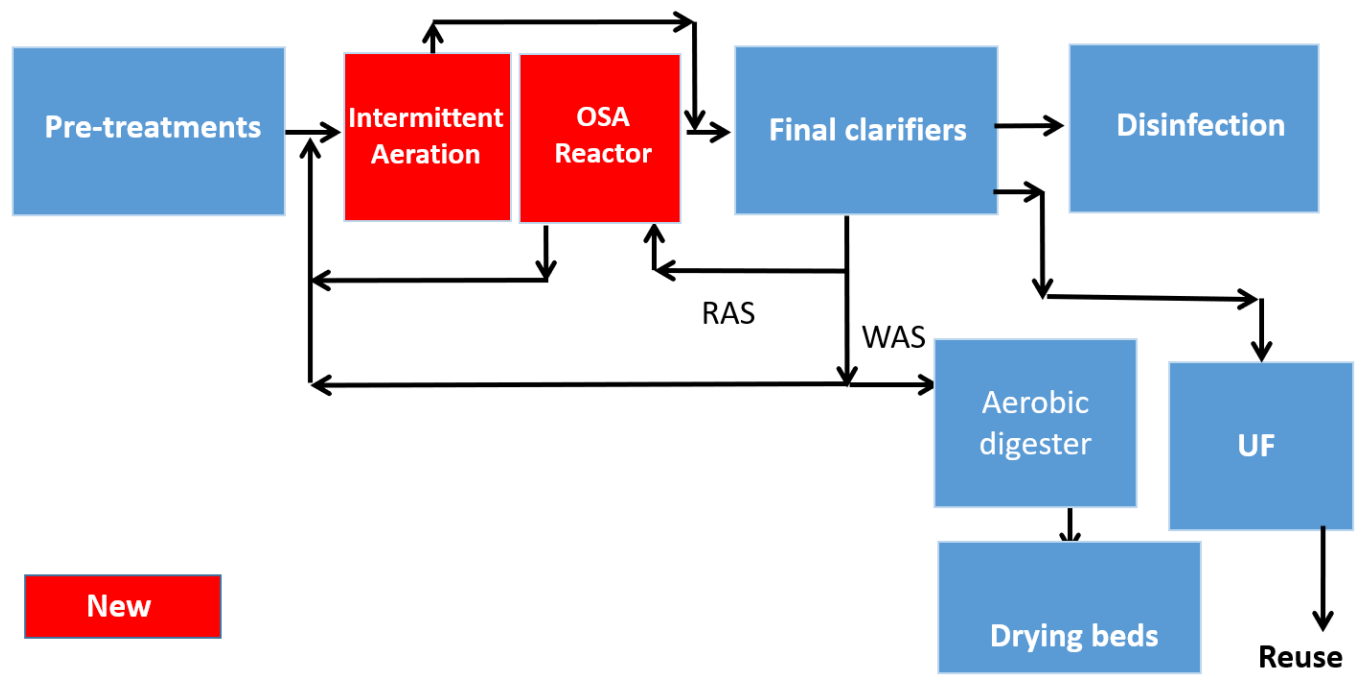

Figure 2. CAS-OSA full-scale plant configuration.

In the CAS-OSA configuration, an anaerobic/anoxic environment reactor is inserted before the recycled sludge (coming from the settler) reaches the aerobic reactor. The anoxic/anaerobic conditions will promote a stress condition in the biomass that will cause a metabolic split between anabolism and catabolism, which should slow down the biomass production and bacterial growth [18]. Indeed, under the metabolic uncoupling conditions, since part of the energy is consumed for microorganism maintenance, their growth is inhibited, thus leading to a reduction in sludge production $[19,20]$.

Moreover, a new aeration system for the activated sludge reactors has been designed and realized. Specifically, the old surface turbine aerators of the activated sludge reactors have been replaced with a diffused aeration system. Traditional design criteria have been adopted for the calculations [2]. For each of the existing activated sludge reactors, the amount of the required air flow $\left(492 \mathrm{~m}^{3} / \mathrm{h}\right)$ and the blower power $(8000 \mathrm{~W})$ have been assessed. With this regard, 100 fine-bubble diffusers (nominal pore size, $\mathrm{d}<3$-mm bubbles) 
have been installed at the bottom of each activated sludge reactor. The adoption of the new aeration system by blowers will allow applying SMART control solutions (e.g., by means of a proportional-integral-derivative PID) for reducing the plant energy demand.

In addition to the implementation of the OSA process in the plant, an intermittent aeration process will be implemented in order to make possible the denitrification process and, consequently, improve the quality of the effluent.

Furthermore, in view of optimizing the WWTP in terms of process efficiency and energy consumption, the sludge recycling pumps (from the settlers to the activated sludge reactors) have been replaced with new pumps able to be automatically controlled.

The ultrafiltration system has never started. Therefore, within the Wider-Uptake Project, the membrane maintenance is going to be performed in view of operating the ultrafiltration system to produce water to be reused for the irrigation of Corleone's municipal gardens.

Notwithstanding the reduction of sludge production by the implementation of the OSA system, a slight amount of excess sludge will be inevitably produced. In a circular economy point of view, the sludge will be subjected to composting and, thus, transformed into agricultural soil conditioner. In this regard, the sludge composting activities will be carried out in aerated piles of sludge mixed with bulking agents under different configurations characterized by different operational conditions and composition in order to achieve the best compost quality. The produced compost will be applied to soil and on potted plants as a soil conditioner, and the role/effect on plant growth will be assessed. The interactions of soil-water-plants will be studied both for sludge reuse and water reuse. In particular, the effect of sludge and water reuse on the plant growth quality will be tested.

\subsection{Marineo WWTP}

In the context of the Wider-Uptake Project, the Marineo WWTP is devoted to demonstrating the material recovery from wastewater treatment. Moreover, the plant optimization in terms of energy consumption and GHG emissions will be undertaken.

Within the Wider-Uptake Project, two process lines have been set up as deviation lines from the main wastewater treatment scheme: final filters (columns) filled with biochar and zeolites for nutrient (N and $\mathrm{P}$ ) recovery (Figure $3 \mathrm{c}$ ) and a pilot plant for polyhydroxyalkanoate (PHA) production (Figure 3d). The goal is twofold: on the one hand, the enhancement of nutrients recovery by using two different adsorption materials (e.g., biochar and zeolites), while, on the other hand, different plant operational conditions will be investigated in order to maximize the PHA accumulation within the biomass and minimize the energy consumption and GHG emissions (both direct and indirect).
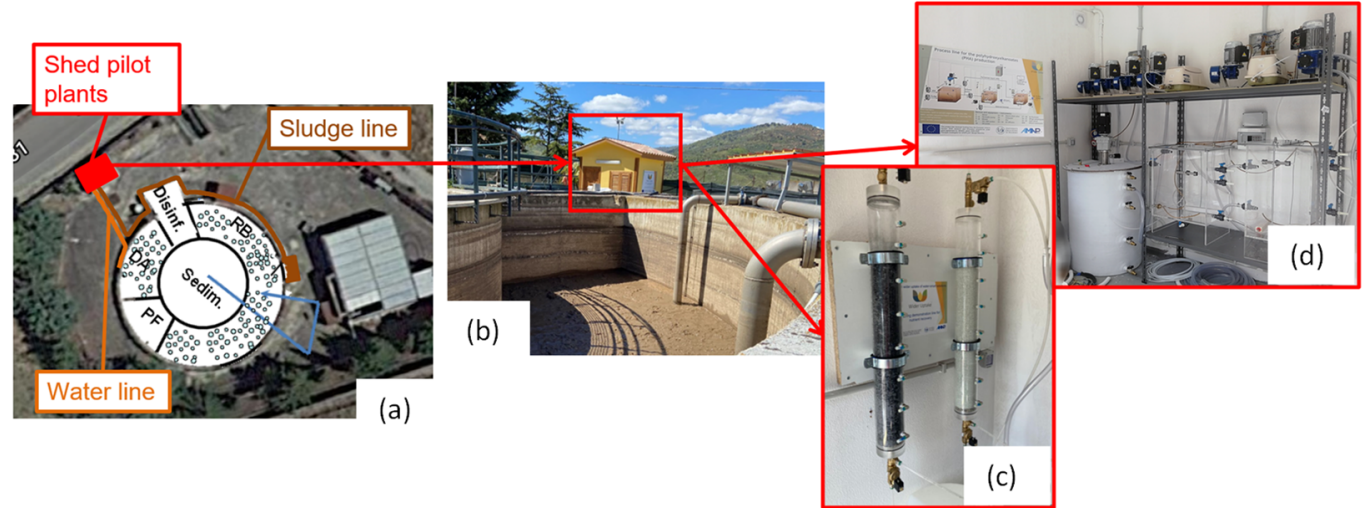

Figure 3. Modified orthophoto of the combined basin under study (a), particularly of the WiderUptake Shed (b), and the deviation lines for nutrient adsorption (c) and PHA production (d).

In particular, the deviation line for PHA recovery (Figure 4) is characterized by a fermenter unit for volatile fatty acid (VFA) production (namely, F-SBR), an ultrafiltration membrane for VFA-rich fermentation liquid separation, a sequencing batch reactor for 
the growth of the PHA-accumulating organism (namely, S-SBR) and a sequencing batch reactor for the accumulation of PHA (namely, A-SBR). The deviation line can treat around $40 \mathrm{~L} /$ day of the waste-activated sludge produced by the full-scale treatment line.
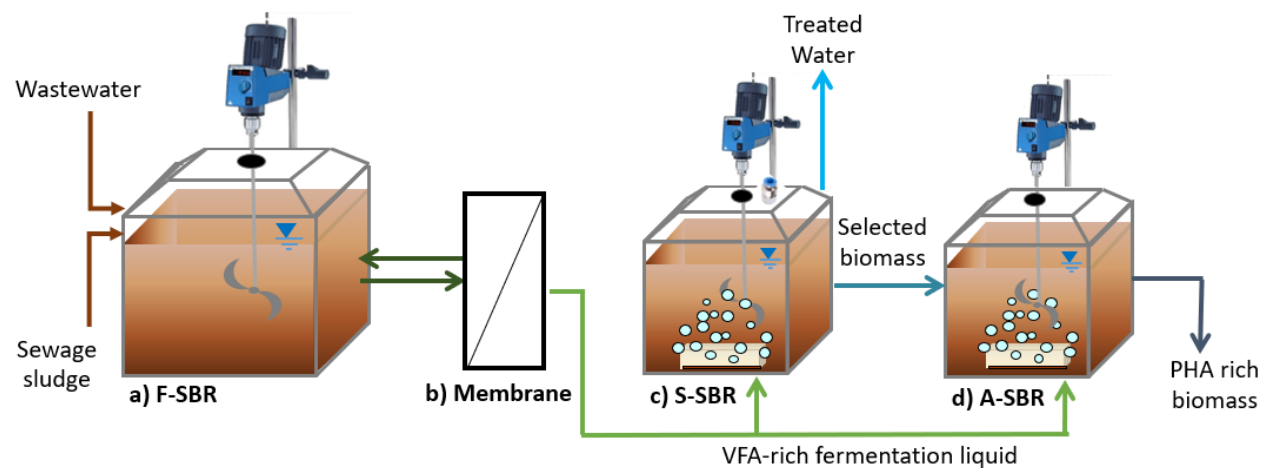

Figure 4. PHA pilot plant configuration. (a) Sequencing batch fermentation reactor (F-SBR), (b) Ultrafiltration membrane, (c) selection sequencing batch reactor (S-SBR) and (d) accumulation sequencing batch reactor (A-SBR).

This pilot plant is aimed at enhancing the state-of-the-art PHA production from urban wastewater with the use of high SRT waste activate sludge (WAS) as the substrate for VFA production [21,22]. Indeed, WAS produced from high SRT processes are not considered as good feedstock for PHA production processes, due to its fermentation toughness. Due to their low biodegradability, low VFA yields are obtained compared to primary sludge or low SRT WAS that have a better acidogenic potential [23,24].

The pilot scale plant for $\mathrm{N}$ and $\mathrm{P}$ recovery consists of adsorption columns (Figure 5). Specifically, two columns filled with adsorbent materials (biochar and clinoptilolite) have been set up and will be fed in the downward mode with treated wastewaters. Clinoptilolite is a specific type of zeolite, the most commonly adopted. The flow rate will be $0.36 \mathrm{~m}^{3} \mathrm{~d}^{-1}$. The zeolite column is equipped with a backwash system with an upward flow in order to keep clean the adsorbent material and with different sampling points to evaluate the nutrient's adsorption kinetics. Zeolite and biochar inside the columns will be used to adsorb $\mathrm{N}$ and $\mathrm{P}$, respectively. In order to allow the reuse of the zeolites for multiple cycles, after the adsorption cycle, zeolites will be regenerated by $1-\mathrm{M} \mathrm{NaCl}$ solution washing to desorb the recovered $\mathrm{NH}_{4}{ }^{+}$. When exhausted, zeolites will be applied to the soil as a conditioner. On the other hand, the biochar column is not provided with a backwash system, because $\mathrm{P}$ is mainly irreversibly retained. When the biochar is exhausted, it will be directly applied to soil as both the $\mathrm{CO}_{2}$ sink and slow-release fertilizer [25].

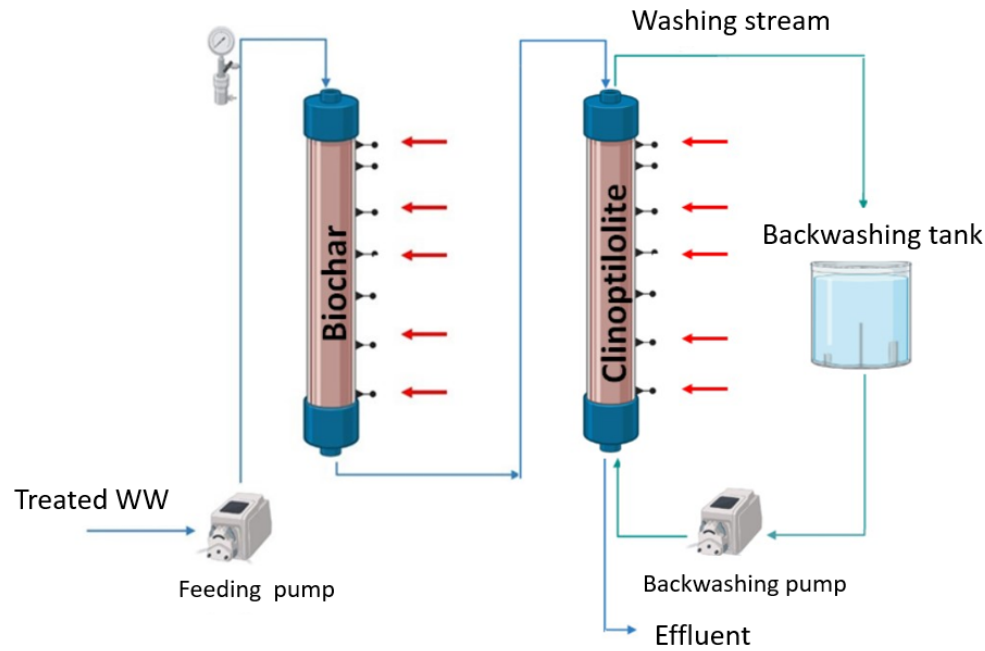

Figure 5. Nutrient recovery plant operating scheme. 


\section{Materials and Methods}

\subsection{Historical Data Analysis and Monitoring Campaign}

After a preliminary analysis of the WWTP historical monitoring data (period: 2015-2020), an ad hoc monitoring campaign was designed and carried out. Indeed, for both WWTPs, three plant sections were monitored: (1) inlet wastewater fed to the activated sludge reactor, (2) treated water effluent from the disinfection tank and (3) MLSS inside the activated sludge reactor.

In Figures 6 and 7, the sampling section locations are reported for the Marineo and Corleone WWTPs, respectively.
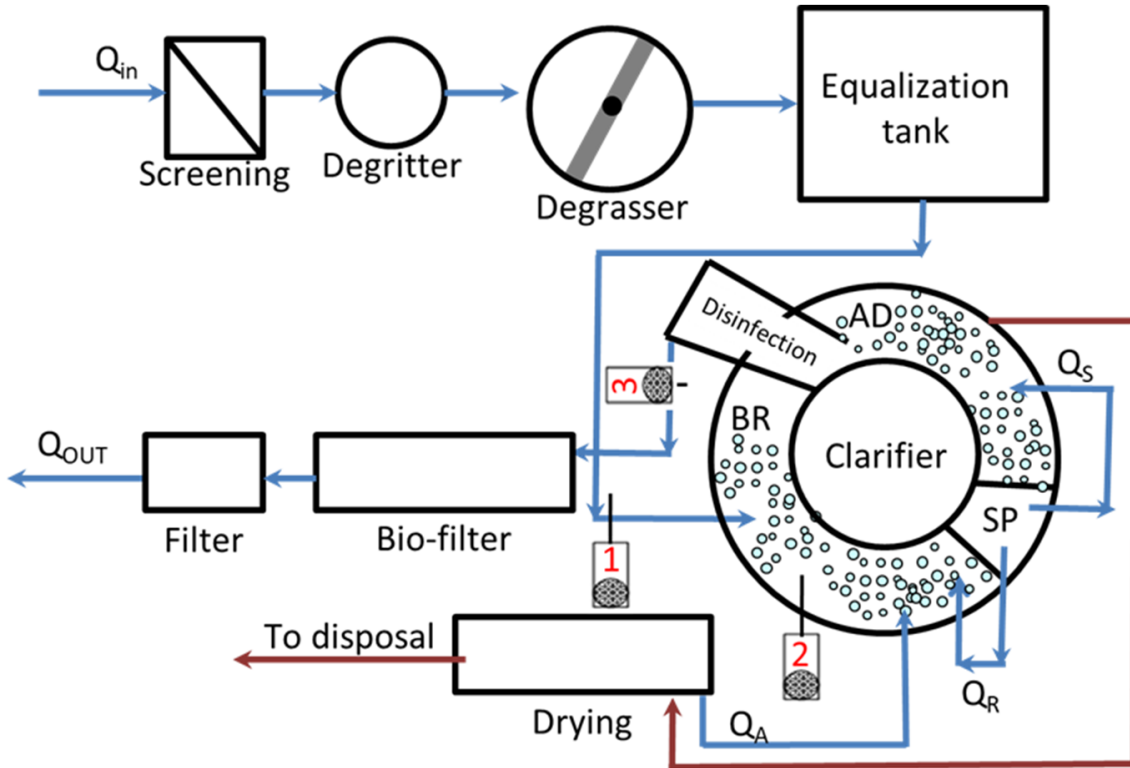

\begin{tabular}{|lll|}
\hline Sampling section & \multicolumn{1}{c|}{ BR= Biological reactor $\quad A D=$ Aerobic digester } \\
$\mathrm{Q}_{\text {in }}=$ influent flow & $\mathrm{Q}_{\mathrm{OUT}}=$ effluent flow $\quad \mathrm{Q}_{\mathrm{R}}=$ recirculation flow & $\mathrm{SP}=$ Sludge pit \\
$\mathrm{Q}_{\mathrm{A}}=$ sludge water & $\mathrm{Q}_{\mathrm{S}}=$ waste activated sludge & Digested sludge \\
\hline
\end{tabular}

Figure 6. Schematic representation of the Marineo WWTP.

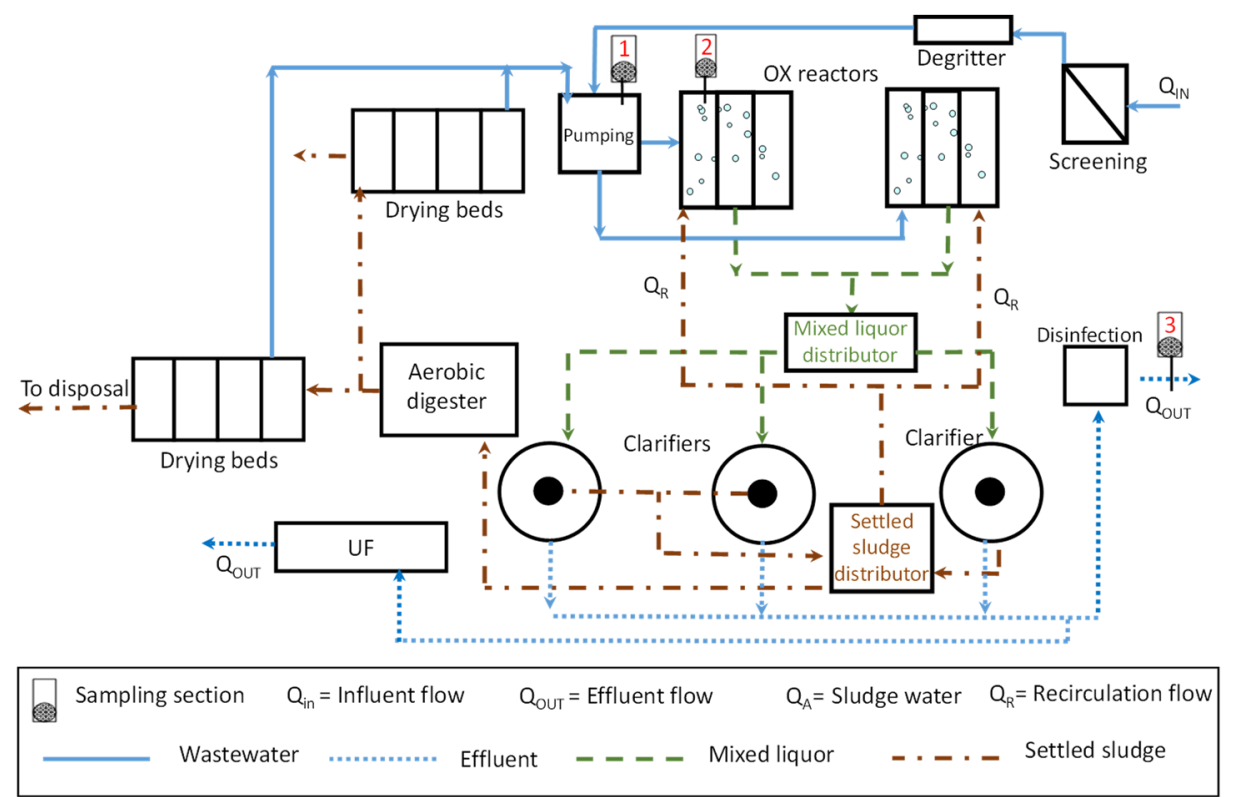

Figure 7. Schematic representation of the Corleone WWTP. 
For Sections 1 and 3, automatic samplers were adopted and set considering the hydraulic retention time (HRT) inside the activated sludge system (namely, $11 \mathrm{~h}$ for Marineo and $10 \mathrm{~h}$ for Corleone).

Concerning the samples for Section 3, the samples were withdrawn manually.

Table 2 summarizes the parameter analyzed for each section.

Table 2. List of parameters analyzed in each sampling section for both WWTPs.

\begin{tabular}{cccc}
\hline Parameter & $\mathbf{1}$ & Sampling Sections & \\
& $\mathrm{X}$ & $\mathbf{2}$ & $\mathbf{3}$ \\
\hline $\mathrm{BOD}_{5}$ & $\mathrm{X}$ & $\mathrm{X}$ \\
\hline $\mathrm{COD}_{\mathrm{TOT}}$ & $\mathrm{X}$ & $\mathrm{X}$ \\
\hline $\mathrm{N}_{\mathrm{TOT}}$ & $\mathrm{X}$ & $\mathrm{X}$ \\
\hline $\mathrm{NH}_{4}{ }^{+}$ & $\mathrm{X}$ & $\mathrm{X}$ \\
\hline $\mathrm{NO}_{3}{ }^{-}$ & $\mathrm{X}$ & $\mathrm{X}$ \\
\hline $\mathrm{NO}_{2}{ }^{-}$ & $\mathrm{X}$ & $\mathrm{X}$ \\
\hline $\mathrm{P}_{\mathrm{TOT}}$ & $\mathrm{X}$ & $\mathrm{X}$ \\
\hline $\mathrm{PO}_{4}{ }^{3-}$ & $\mathrm{X}$ & $\mathrm{X}$ \\
\hline $\mathrm{SST}$ & $\mathrm{X}$ & $\mathrm{X}$ \\
\hline $\mathrm{SSV}$ & & $\mathrm{X}$ & $\mathrm{X}$ \\
\hline DSVI/SVI & & $\mathrm{X}$ & \\
\hline Clarifier performance & $\mathrm{X}$ & \\
\hline
\end{tabular}

\subsection{Clarifier Performance Verification}

The secondary clarifiers verification was performed by using the State Point Analysis (SPA) method [26]. The method is based on the solids mass balance around the clarifier under the following conditions: (i) steady-state conditions, (ii) only one vertical dimension is considered, (iii) sludge compression is neglected and (iv) effluent solids are neglected.

According to the SPA method, the clarifier operating conditions can be evaluated by means of:

$\checkmark \quad$ hydraulic capacity evaluation (detention time, surface overflow rate (SOR) and weir overflow rate (WOR)) and

$\checkmark \quad$ solids loading capacity or solids loading rate (SLR).

The SPA method allows to graphically evaluate the settler "state point" in a graph where the underflow rate line (UR), SOR line and settling flux curve are depicted. The "state point" represents the cross-point between the UR and SOR lines. Under stable operation conditions, the "state point" must be located well below the settling flux curve.

The following steps were followed:

$\checkmark \quad$ acquire the clarifier data (number of clarifiers in operation, clarifier surface, mixed liquor suspended solid-MLSS concentration, influent flow rate and return activated sludge-RAS flow rate);

$\checkmark \quad$ build the sludge settling curve representing how the sludge settling velocity varies with the MLSS concentration [27];

$\checkmark \quad$ build the settling flux curve and

$\checkmark \quad$ draw the settling flux curve, SOR and UR line in a graph and identify the state point.

The sludge settling curve was built by performing 30-min batch settling tests under different TSS concentrations and using a 1-L graduated glass cylinder. During the batch settling tests, the position of the suspension-liquid interface was measured at different time intervals. Therefore, the evolution of the sludge blanket height over time during the batch settling test was calculated [27]. For each batch test, the slope of the initial linear tendency was the settling velocity $\left(V_{i}\right)$ related to the reference TSS concentration $\left(C_{i}\right)$. Consequently, 
by performing the test for different TSS concentrations, the curve settling velocity/TSS concentration can be drawn. The experimental settling velocity can be described according to Equation (1).

$$
V_{i}=V_{0} \times e^{-k \times C_{i}}
$$

where $V_{0}$ and $k$ are the empirical parameters.

Moreover, by using the 30-min sludge volume, the Sludge Volume Index (SVI) or Diluted Sludge Volume Index (DSVI) can be evaluated according to Equation (2) and Equation (3), respectively.

$$
S V I\left(\frac{\mathrm{mL}}{g S S}\right)=\frac{S S V_{30} \times(1000 \mathrm{mg} / \mathrm{g})}{X \cdot V_{T}}
$$

where

$S S V_{30}=30$-min settle sludge volume $(\mathrm{mL})$,

$X=$ mixed liquor suspended solids concentration $(\mathrm{mg} / \mathrm{L})$ and

$V_{T}=$ volume of the settle column.

$$
D S V I\left(\frac{\mathrm{mL}}{g S S}\right)=\frac{D S V_{30}}{X_{d}}
$$

where

$D S V_{30}=30$-min settled sludge volume of diluted sludge and $X_{d}=$ mixed liquor suspended solids concentration $(\mathrm{mg} / \mathrm{L})$ after dilution.

\subsection{Batch Tests}

Preliminary tests were carried out at the laboratory scale to evaluate the effect of chemical treatments of clinoptilolite, the most natural abundant zeolite with a high affinity for $\mathrm{NH}_{4}{ }^{+}$[28], with the aim to improve the operational capacity of clinoptilolite. For further details on the clinoptilolite used in this study, the reader is referred to the literature [29].

The static $\mathrm{NH}_{4}{ }^{+}$adsorption was carried out with $2 \mathrm{~g}$ of untreated and treated clinoptilolite. The samples were shaken with $200 \mathrm{~mL}$ of $1000-\mathrm{mg} \mathrm{NH}_{4}{ }^{+} \mathrm{L}^{-1}$ in an orbital shaker for $24 \mathrm{~h}$. The amount of $\mathrm{NH}_{4}{ }^{+}$adsorbed was determined using one gram of clinoptilolite by Kjeldahl distillation with $30 \mathrm{~mL}$ of $33 \% \mathrm{NaOH}$ solution for six minutes. For the desorption, $1 \mathrm{~g}$ of $\mathrm{NH}_{4}{ }^{+}$-enriched clinoptilolite was shaken with $100 \mathrm{~mL}$ of a $1-\mathrm{M} \mathrm{NaCl}$ solution on a horizontal shaker for $48 \mathrm{~h}$. The amount of $\mathrm{NH}_{4}{ }^{+}$desorbed was determine by Kjeldahl distillation with $30 \mathrm{~mL}$ of $33 \% \mathrm{NaOH}$ solution for six minutes. The amount of $\mathrm{NH}_{4}{ }^{+}$desorbed was calculated as the difference between adsorbed (total) and retained (not exchanged by $\left.\mathrm{Na}^{+}\right) \mathrm{NH}_{4}{ }^{+}$. Adsorption kinetics were assessed as reported by Muscarella et al. [29].

Preliminary tests were performed on sewage sludge collected from the sludge recycle line at the Marineo WWTP. The raw sludge was characterized by measuring its physicochemical characteristics and monitoring their variations over a 12-week period on four different samples taken at 3-week intervals. The sludge acidogenic potential under different operational conditions was measured trough acidogenic fermentation batch tests performed in 1-L magnetic stirred glass reactors [30].

\subsection{Governance Analysis}

The Governance assessment for Circular Economy based on Water resources (GOCIWA) is a governmental analysis tool, developed within the Wider-Uptake Project to allow the preliminary identification of barriers (social, technological, regulatory, organizational and economic) that hinder the transition path from a linear to a circular economy model in the wastewater sector and to identify actions to overcome them. The identification of these barriers takes place through a participatory process involving all the actors participating in the Wider-Uptake Project. 
This tool is divided into three levels, with the aim of being able to better analyze the multi-layered context to which the actors belong. The three levels are interconnected, as shown in Figure 8, and can be summarized as follows.

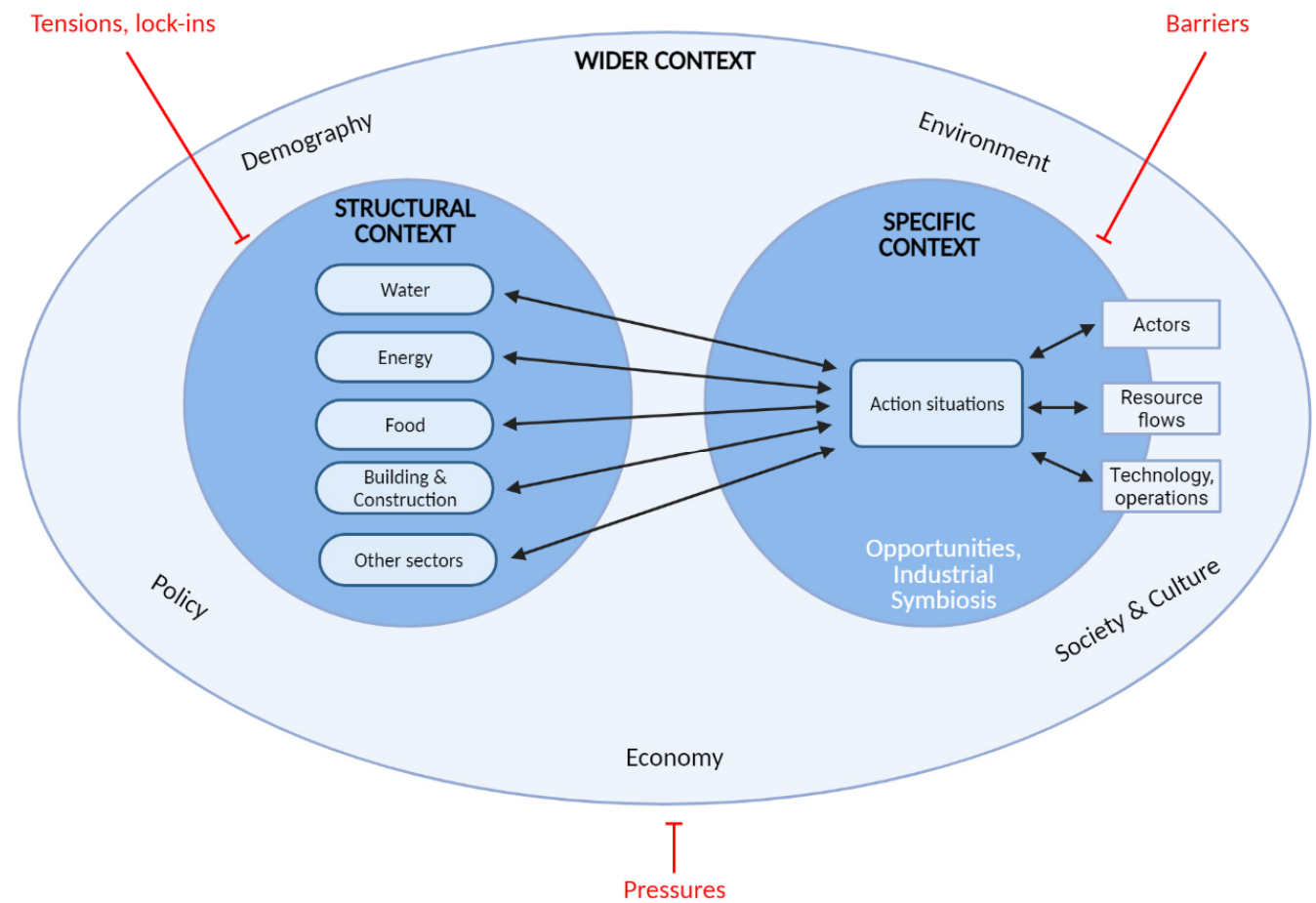

Figure 8. General flow chart for the governance assessment. Relationship between the various levels, key points and existing barriers.

1. The wider context refers to a broad view of the political, economic, social and cultural scenarios in which governance regimes are situated and includes the effects of market dynamics and environmental changes. To describe it, the focus is on five key aspects, namely: Sociocultural Scenario, Population and Urbanization, Environmental Challenges, Political Context and Economic Conditions.

2. The structural context includes the established governance regime and related rights of ownership and use, as well as the prevailing practices that characterize the current situation. To describe this context, six fundamental aspects are considered, namely: Levels and Scales, Prevailing Technologies, Actors and Networks, Perspectives and Ambitions, Strategies and Tools and Accountability and Resources. The main barriers to overcome are "Tensions" and "Lock-ins". A Community of Practice (CoP) was established in order to form a group of professionals, experts, companies and associations orbiting around the main themes of the project. The CoP will be used to share the perspectives of water utilities, solution providers and stakeholders from different industry sectors to jointly develop the technical, marketing and commercial aspects of the water-smart systems.

3. Context-specific deals with assessing the factors directly related to the case studies, such as the geographical location of the systems and their histories, which consist of a previous decision-making and framing process. At this level, the aspects to be evaluated are previous decisions and case-specific circumstances.

At this level, the process of forming an industrial symbiosis regime is important, fostered by the interaction between the structural context and the actors, the flow of resources and the operating technologies. 


\section{Preliminary Results}

\subsection{Brief Analysis of Historical Data}

Historical data in terms of BOD, COD and TSS were analyzed for the years 2015-2020 (around 50 data for each measured parameter). The data showed good behaviors of both WWTPs with two effluent excess values compared to the legislative limit for $\mathrm{BOD}_{5}$ in Corleone in 2017 (namely, 170 and $94 \mathrm{mg} / \mathrm{L}$ ).

For the sake of conciseness, the data related to the influent and effluent COD for the Corleone and Marineo WWTPs are reported in Figure 9.

(a)

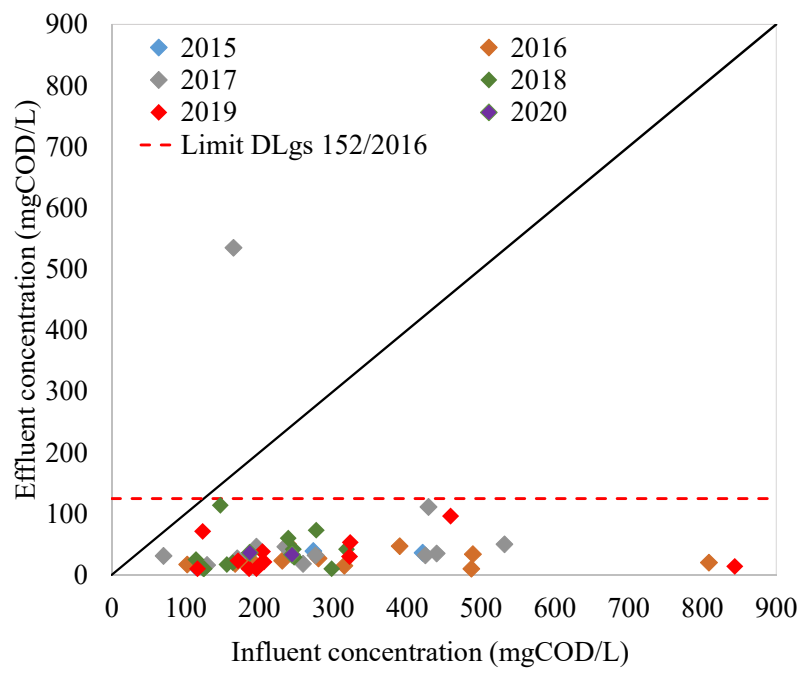

(b)

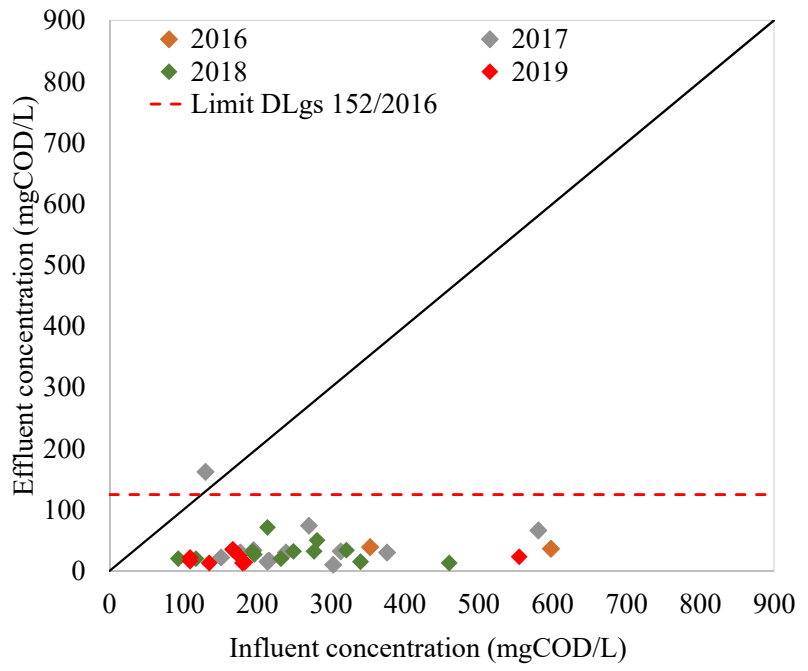

Figure 9. Influent and effluent COD concentration for the Corleone (a) and Marineo (b) WWTPs during the years 2015-2020.

The data of Figure 9 show that, in 2017, the COD was higher than the limit for both plants.

In terms of the TSS concentration, excess effluent values (four out of 50 data for Corleone and six out of 50 data for Marineo) were obtained during the period 2015-2020.

\subsection{Monitoring Campaign Results for Corleone and Marineo WWTPs}

The influent COD concentration in Corleone ranged between 125 and $320 \mathrm{mg} / \mathrm{L}$ (Figure 10a). These values were quite low compared to the typical urban wastewater COD concentration [2]. This result was likely due to wastewater dilution caused by parasitic clear water infiltration. In terms of COD removal, the imposed regulatory limits were always complied by (Figure 10a). Important to precision was that, since the ultrafiltration system was yet started, here, we refer to the imposed regulatory limits for the discharge in the water body. Regarding the influent TSS, a similar dilution effect as discussed for the COD was observed. Indeed, the influent TSS concentration ranged between 130 and $380 \mathrm{mg} / \mathrm{L}$ (Figure 10b). In terms of the effluent TSS concentration, the discharge limit of $35 \mathrm{mg} / \mathrm{L}$ was always exceeded. This circumstance will be discussed in detail below. Mixed liquor TSS and VSS data are reported in Figure 10c. The achieved data showed that the TSS concentration slightly increased during the monitoring day (from 2.7 to $4.8 \mathrm{~g} / \mathrm{L}$ ); this result was likely due to the sludge withdrawal operations from the secondary clarifier to the sludge line. Indeed, the sludge withdrawal occurred discontinuously and only at the end of the day. 

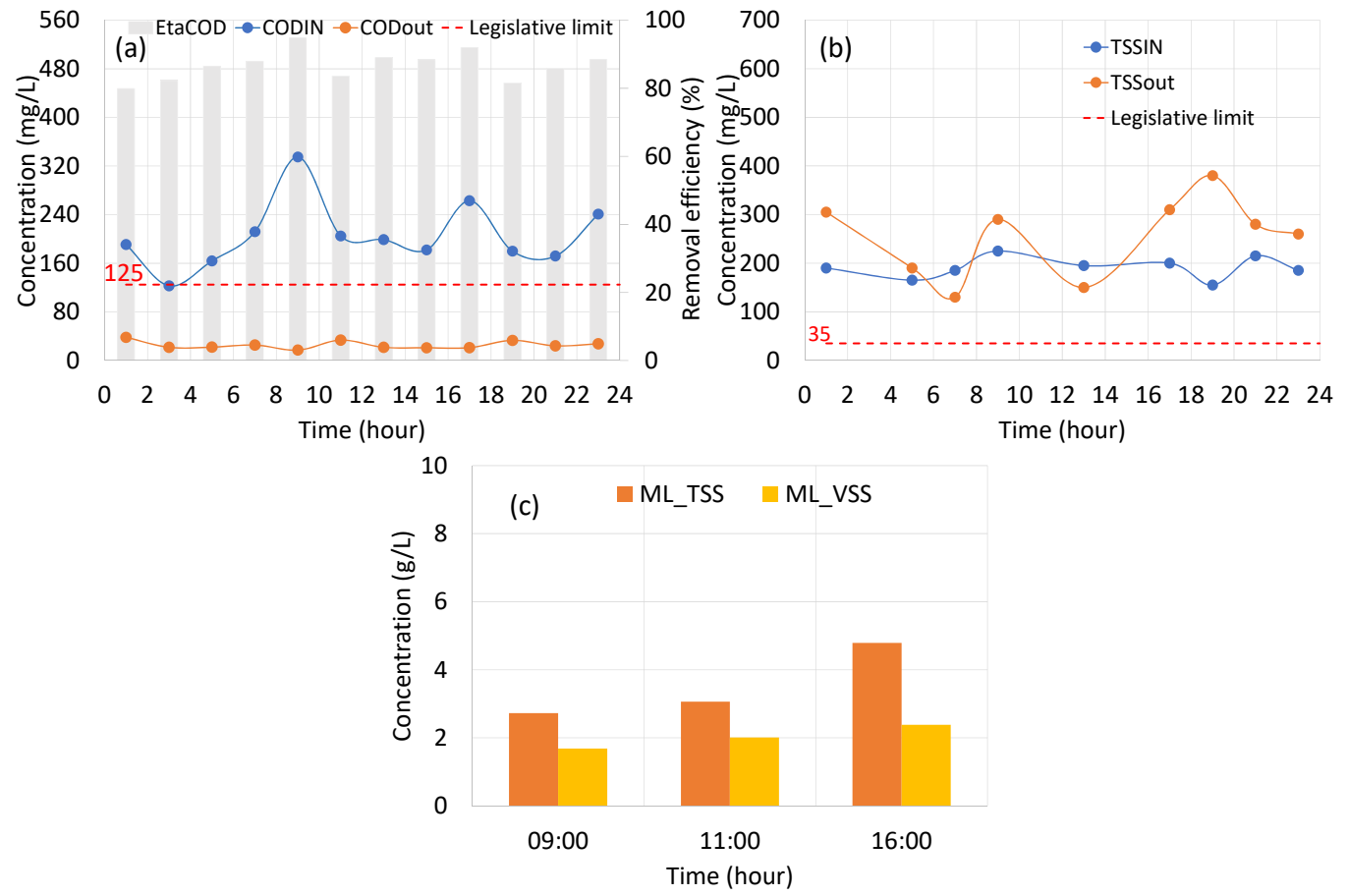

Figure 10. The trend of influent (IN, Section 1) and effluent (out, Section 3) measured the COD, removal efficiency (EtaCOD) and legislative limit (a); the trend of influent (IN) and effluent (out) measured the TSS and legislative limit (b) and measured the mixed liquor (Section 2) TSS (ML_TSS) and VSS (ML_VSS) (c) Corleone WWTP.

The influent COD concentration in Marineo ranged between 214 and $379 \mathrm{mg} / \mathrm{L}$ (Figure 11a). In terms of COD removal, the regulatory limit was generally met, excepting for three samples. Indeed, on average, the COD removal efficiency was lower (64\%) than that imposed by the Italian Regulation (DLgs 152/2006) (at least 75\%) (Figure 11a). The influent TSS concentration ranged between 145 and $300 \mathrm{mg} / \mathrm{L}$ (Figure 11b). In terms of the effluent TSS concentration, the discharge limit of $35 \mathrm{mg} / \mathrm{L}$ was always exceeded. This circumstance will be discussed in detail below. The data of mixed liquor TSS and VSS reported in Figure 11c show that the TSS concentration was higher than the typical operation value for activated sludge systems. Indeed, the observed ML TSS concentration was close to $8 \mathrm{~g} / \mathrm{L}$, three times higher than the typical operational value $(2.5-3 \mathrm{~g} / \mathrm{L})$. As discussed below, this latter result could imply severe effects on the clarifier solid loading rate and, consequently, on the TSS effluent concentration. Moreover, from Figure 11c, it can be deduced that the ratio between the VSS and TSS was lower than the typical value (0.7). Indeed, on average, the VSS/TSS ratio was equal to 0.5 . This result can be due to the high sludge retention time (SRT) of the activated sludge reactor that allowed the establishment of endogenous biomass conditions within the aerobic biological reactor [2]. 


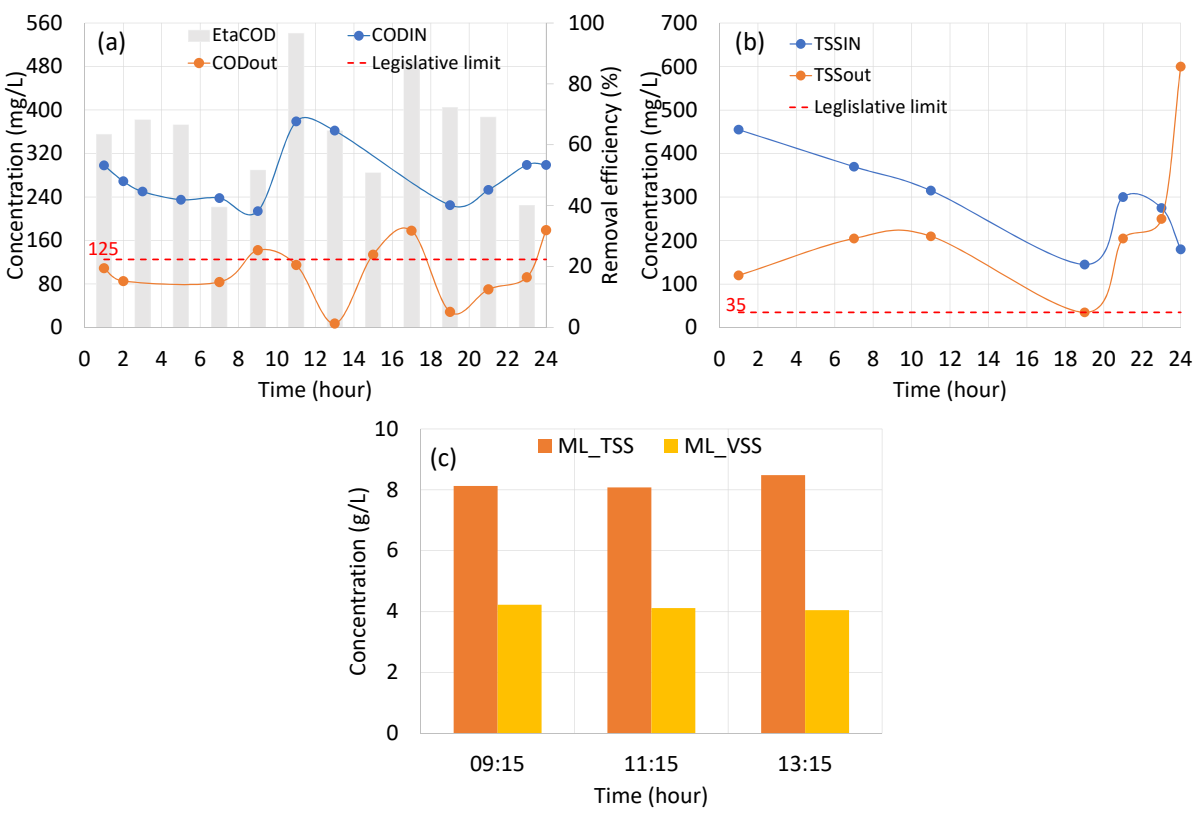

Figure 11. The trend of influent (IN, Section 1) and effluent (out, Section 3) measured the COD, removal efficiency (EtaCOD) and legislative limit (a); the trend of influent (IN) and effluent (out) measured the TSS and legislative limit (b) and measured the mixed liquor (Section 2) TSS (ML_TSS) and VSS (ML_VSS) (c) Marineo WWTP.

\subsection{Clarifier Verification for Corleone and Marineo WWTPs}

For Corleone WWTP, the settling velocity curve, calculated by diluting the MLSS samples, showed that the velocity ranges between 4.3 and $0.5 \mathrm{~m} / \mathrm{h}$ for 0.8 and $2.8 \mathrm{gTSS} / \mathrm{L}$, respectively (Figure 12a). This result is in accordance with the typical values suggested in the literature (around $4 \mathrm{~m} / \mathrm{h}$ for 2.8-3-gTSS/L) [31]. However, the obtained SVI value (equal to $128 \mathrm{~mL} / \mathrm{gTSS}$ ) suggests that the sludge has a poor settling capability. Moreover, since, after 30-min settling, the sludge is not compact and the $\mathrm{SSV}_{30}$ is high, the presence of filaments bacteria is suggested [2]. This circumstance is likely due to the poor mixed liquor aeration caused by the old surface aeration system, since plant monitoring was performed before the aeration system replacement. The data reported in Figure $12 \mathrm{~b}$ show that the state point is within the settling flux curve, thus suggesting that the clarifier is not overloaded. This result corroborates the fact that the high TSS effluent concentration can be due to the poor biomass settling properties and to the likely filamentous bacteria presence. The settling velocity curve calculated by diluting the MLSS for the Marineo WWTP shows that the velocity ranges between 2.89 and $0.027 \mathrm{~m} / \mathrm{h}$ for 2 and 8-gTSS/L, respectively (Figure 12c). The obtained DSVI value (equal to 70-mL/gTSS) for the Marineo WWTP suggests that the sludge has good settling capability. However, the data of Figure $12 \mathrm{~d}$ show that the state point is outside the settling flux curve, thus suggesting that the clarifier is strongly overloaded due to the high TSS concentration inside the aerobic reactor. The clarifier overloading is the reason for the high TSS effluent concentration. The increasing of sludge withdrawing from the bottom clarifier and the consequent TSS reduction within the biological reactor could improve the clarifier behavior. 

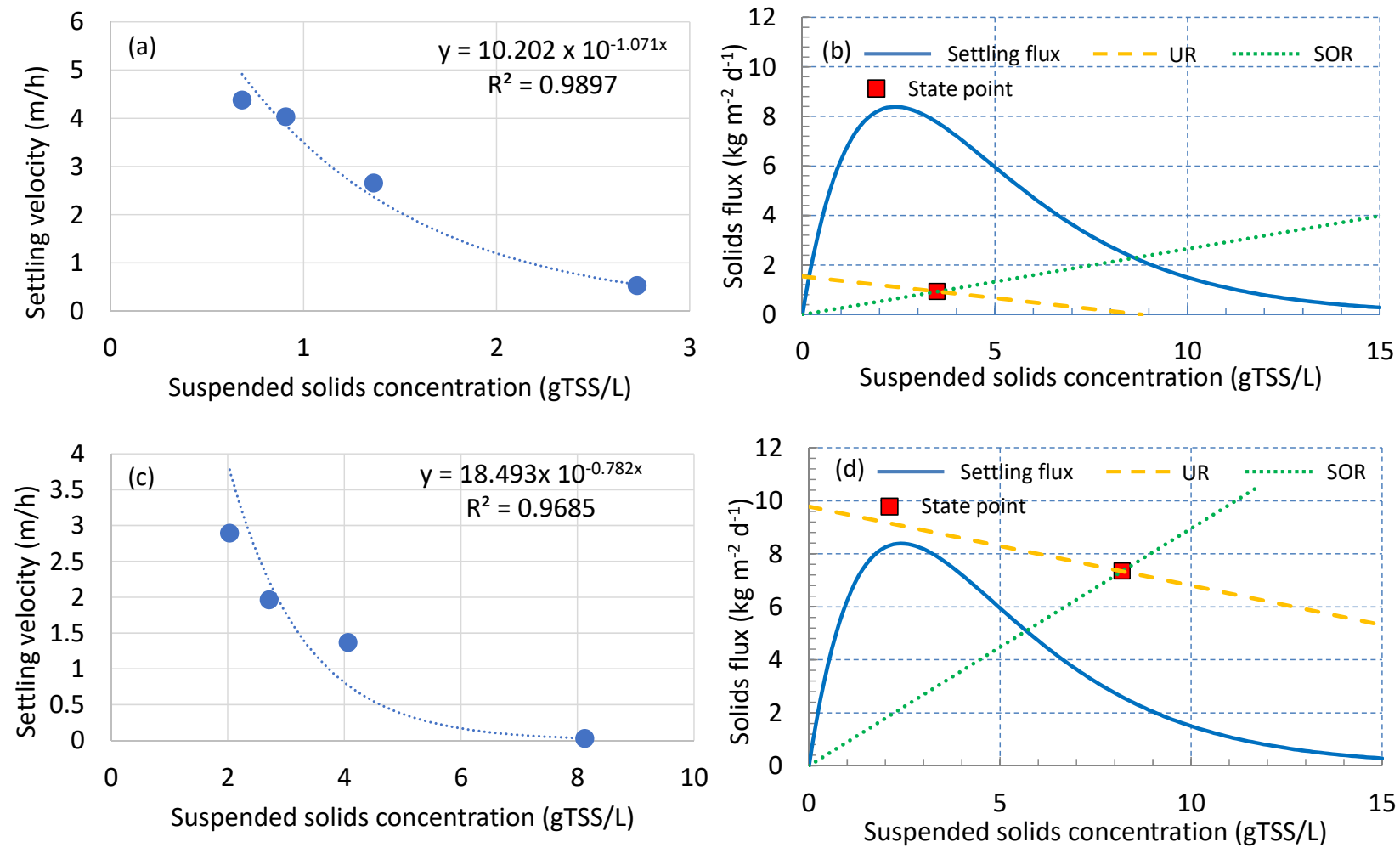

Figure 12. Settling velocity curve (a) and STA application results (b) for Corleone WWTP, and settling velocity curve (c) and STA application results (d) for Marineo WWTP.

\subsection{Batch Test Preliminary Results}

The data reported in Figure 13a show the retained, released and adsorbed amount of $\mathrm{NH}_{4}{ }^{+}$. The highest amount of $\mathrm{NH}_{4}{ }^{+}$was adsorbed by untreated and $\mathrm{HCl}-\mathrm{Na}$-treated clinoptilolite with an average of $11.8 \mathrm{mg}$ of $\mathrm{NH}_{4}{ }^{+}$adsorbed per gram of clinoptilolite (Figure 13a). This result contrasts with the literature, where it is reported that a strong acid treatment can cause dealumination [32]. The lowest amount of $\mathrm{NH}_{4}{ }^{+}$was adsorbed by $\mathrm{NaOH}-\mathrm{Mg}$, with a quantity of $27 \%$ lower than untreated and HCl-Na-treated clinoptilolite. Except for the $\mathrm{HCl}-\mathrm{Na}$ treatment, the two proposed treatments did not improve the adsorption capacity of untreated clinoptilolite [29]. Regarding desorption, it was observed that the amount of $\mathrm{NH}_{4}{ }^{+}$released after $48 \mathrm{~h}$ ranged from 76 to $83 \%$ and was closely related to the amount of $\mathrm{NH}_{4}{ }^{+}$previously adsorbed (Figure 13).

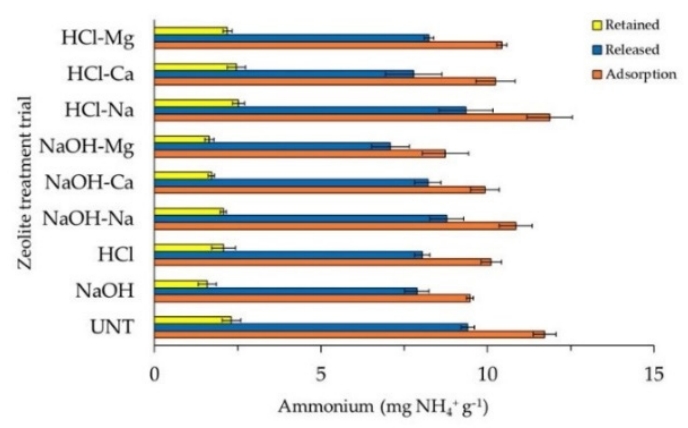

(a)

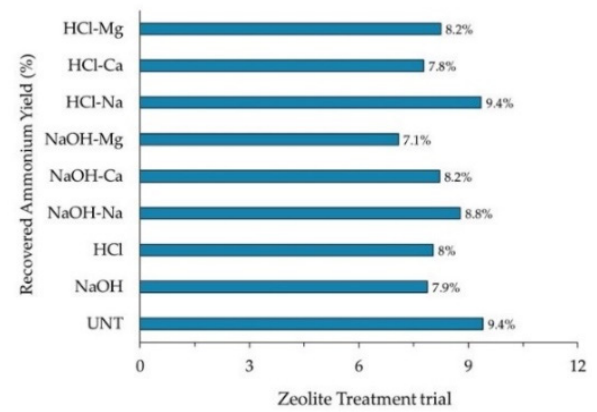

(b)

Figure 13. Amount of $\mathrm{NH}_{4}{ }^{+}$adsorbed, released and retained by the different treatments (a). Percentage of ammonium recovered from the ammonium solution (process efficiency) compared to the ammonium exchange capacity of treated clinoptilolite $(\mathbf{b})$. 
In this study, another parameter evaluated was the efficiency of the entire adsorption and desorption process, such as the percentage of $\mathrm{NH}_{4}{ }^{+}$recovered from the solution compared to the $\mathrm{NH}_{4}{ }^{+}$adsorbed by chemically treated zeolites. The highest efficiency was observed in treated and $\mathrm{HCl}-\mathrm{Na}$-treated clinoptilolite, the lowest in $\mathrm{NaOH}$-pretreated and $\mathrm{NaOH}-\mathrm{Mg}$ (Figure 13b) [29].

The dynamic adsorption tests showed how adsorption proceeds for $48 \mathrm{~h}$. The kinetics showed that all treatments completed adsorption within $24 \mathrm{~h}$; in the case of $\mathrm{NaOH}$ pretreated clinoptilolite and $\mathrm{NaOH}-\mathrm{Mg}$-treated clinoptilolite, adsorption was almost complete within $8 \mathrm{~h}$. These results suggested that $\mathrm{NaOH}$-pretreated clinoptilolite saturated the exchange sites faster than $\mathrm{HCl}$-pretreated clinoptilolite. However, towards the end of kinetic adsorption, the amount of $\mathrm{NH}_{4}^{+}$adsorbed was, on average, lower with $\mathrm{NaOH}$-pretreated clinoptilolite than with untreated or HCl-pretreated clinoptilolite [33]. In addition to the pretreatment, the kinetics were also influenced by the treatment with the salts; in fact, there was a higher rate of adsorption for the $\mathrm{Na}^{+}$-treated zeolite than for the treatment with the bivalent cations $\mathrm{Ca}_{2}{ }^{+}$and $\mathrm{Mg}^{+}$, probably due to the stronger bonds that the divalent cations establish with the exchanger and, thus, to their difficult displacement $[29,33]$.

In Table 3 the results of the sludge characterization are reported. The results highlight the variability of the sludge features, especially referring to the suspended solids concentration (Figure 14), probably due to the manual management of sludge wasting operations from the sludge recycle line. Indeed, at present, the sludge discharge is activated manually by the plant operators without a fixed time schedule or discharge duration.

Table 3. Waste-activated sludge features.

\begin{tabular}{lcccc}
\hline Parameters & Week 0 & Week 3 & Week $\mathbf{6}$ & Week 9 \\
\hline $\mathrm{pH}$ & 7.1 & 7.1 & 7.2 & 7.0 \\
Total Suspended solids, TSS (g/L) & 14.74 & 13.4 & 10.08 & 3.95 \\
Volatile Suspended Solids, VSS (g/L) & 6.4 & 5.9 & 5.31 & 1.92 \\
VSS/TSS & 0.43 & 0.44 & 0.52 & 0.48 \\
Total Chemical Oxygen Demands, TCOD (g/L) & 9.89 & 13.39 & 13.73 & 5.93 \\
Soluble Chemical Oxygen Demands, sCOD (g/L) & 0.23 & 0.94 & 0.23 & 0.18 \\
Protein (g/L) & 0.68 & 0.65 & 0.69 & 0.4 \\
Carbohydrate $(\mathrm{g} / \mathrm{L})$ & 0.09 & 0.1 & 0.1 & 0.04 \\
Ammonium, $\mathrm{NH}_{4}{ }^{+}-\mathrm{N}(\mathrm{mg} / \mathrm{L})$ & 4.7 & 8.3 & 9.5 & 24.2 \\
Phosphate, $\mathrm{PO}_{4}{ }^{3-}-\mathrm{P}(\mathrm{mg} / \mathrm{L})$ & 7.4 & 20.8 & 24.0 & 4.5 \\
\hline
\end{tabular}

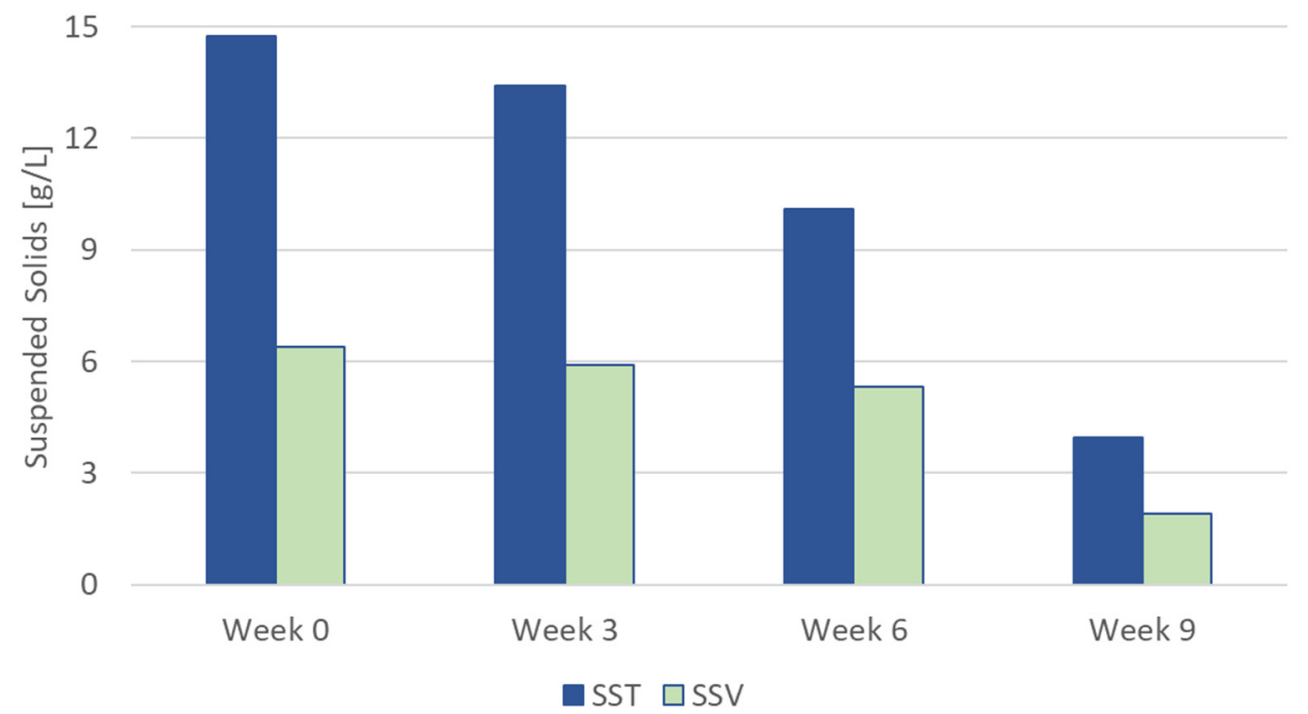

Figure 14. Suspended solids concentrations in the monitored period. 
As expected for sludge produced by a high SRT process, the VSS-to-TSS ratio is low, indicating a low biodegradability. This aspect was confirmed by the acidogenic fermentation tests, in which a maximum VFA concentration of about 2 gCOD/L was obtained [30]. This concentration is indeed lower than those usually reported in the literature for fermentation processes under similar conditions [34-37].

\subsection{COGIWA Application}

The data required for GOCIWA application were collected through semi-structured interviews. The interviews consisted of 41 questions, in turn divided into different levels. The results of the interviews were collected in a database to be easily accessible for a subsequent data analysis.

The application of GOCIWA to Corleone and Marineo case studies has revealed several barriers for the transition from linear to circular economy. Specifically, regarding the wider context, the projection to 2050 revealed that the Sicilian population is decreasing by $9.9 \%$ while the Italian northern region's population will grow by $0.6 \%$ [38]. In addition, the population is mainly located in areas of medium urbanization, which is more relevant in Sicily than in the national context.

Regarding the environmental challenges, to date, $42 \%$ of groundwater is polluted. Further, the mismanagement of water infrastructure causes more than a one-third loss of the water injected into networks $[39,40]$. The interviews revealed both favorable factors and barriers that favor or limit the conversion to a circular economy model and the implementation of water-smart solutions. The favorable factors and barriers that emerged from the interviews regarding the shift from linear to circular economy are summarized in Table 4.

Table 4. Summary table of favorable factors and barriers.

\begin{tabular}{|c|c|}
\hline Favorable Factors & Barriers \\
\hline Economic interest in implementing water-smart solutions & Limited large-scale application of advanced technologies \\
\hline $\begin{array}{l}\text { Interest in recovering reuse systems that were built but never went } \\
\text { into operation }\end{array}$ & Difficulty in creating a market based on recovered resources \\
\hline $\begin{array}{l}\text { Favorable local conditions for reuse of recovered resources in } \\
\text { terms of social acceptance }\end{array}$ & Regulatory limits on the reuse of recovered resources \\
\hline Sufficient technological maturity to implement water-smart solutions & Difficulty in identifying authorities responsible for reusing resources \\
\hline \multirow[t]{4}{*}{ Apparent political will to support transition to circular economy } & Absence or weak interaction with policymakers and decision makers \\
\hline & Lack of collaboration between the various administrative levels \\
\hline & $\begin{array}{l}\text { Fragmented management responsibilities (treatment } \rightarrow \text { AMAP, } \\
\text { reuse } \rightarrow \text { municipalities) }\end{array}$ \\
\hline & Limited interaction of actors with citizen associations \\
\hline
\end{tabular}

Regarding favorable factors, it was found that there is an economic interest, shared by partners and key stakeholders, in implementing water-smart solutions. In addition, there are favorable conditions for the reuse of recovered resources in terms of social acceptance, which is closely linked to the semiarid conditions of the southern regions, which encourage farmers to reuse treated wastewater.

This implementation of water-smart solutions, according to the interviewees, is supported by a local political intent in boosting the transition to circular economy, especially on the part of the municipalities of Marineo and Corleone.

The main barriers limiting the transition to water-smart conditions are the limited large-scale applications of advanced technologies, such as the lack of sludge treatment facilities and final destinations for treated sludge, which can also be the cause of reduced process efficiency, and the difficulty in creating a market based on recovered resources. This last point also depends on an issue related to a lack of knowledge of the products that are obtained as a result of the application of these technologies, and this can be improved through a continuous updating of the actors and a process of information of citizens and 
associations through the organization of workshops and webinars. However, it is essential to emphasize that, in this moment, the actors and stakeholders involved are not engaged in other industrial symbiosis activities, and there are no products derived from water-smart solutions on the local market.

Other barriers to be considered are the regulatory limits for the reuse of recovered resources and the difficulty to identify the authorities responsible for the reuse of resources. In fact, the tools needed to promote the conversion from linear to circular economy include European directives and national legislation, as well as regional regulations. Unfortunately, a lack of coherence between the various pieces of legislation has been observed, often caused by a particularly complex legal framework.

The interviews identified the various administrative levels and competent authorities. Unfortunately, the interviewees also highlighted a lack of interaction with policy and decision-makers and a lack of collaboration between the various administrative levels.

It also emerged that the greatest barrier to the participation of other actors is the lack of involvement by the local institutions.

\section{Conclusions}

This manuscript summarizes preliminary actions and results in roadmapping the transition to Water Resource Recovery Facilities of two Italian wastewater treatment plants: Corleone and Marineo. The transition process is challenging and covers several activities interrelated: governance assessment, evaluation of social acceptability, technical feasibility, etc.

The results presented here underlined that, for both plants under study, there are several aspects that require technical improvement to implement the transition: improve the sludge withdrawal operation in view of avoiding high TSS variation inside the aerobic biological reactor or clarifier overloading. Indeed, both conditions negatively affect the effluent TSS concentrations, often exceeding the imposed limit. In view of applying the water reuse in Corleone, the maintenance of the UF system is also mandatory. In this regard, the role of the local governance is fundamental, since sometimes technical decisions overcome political barriers. Indeed, the governance assessment analysis revealed a sort of lack of "high-level decisions" that influence plant operations that are now limited to complying with the legislative limits without having a market vision of the resources that can be recovered from the WWTP.

The study presented here underlines the great potential of both plants in converting their operation into Water Resource Recovery Facilities.

Author Contributions: Conceptualization, G.M.; Data curation, L.B. (Luigi Badalucco), L.B. (Lorenzo Barbara), V.A.L., S.M.M. and D.P. and Formal analysis, G.M., A.C. and D.D.T. All authors have read and agreed to the published version of the manuscript.

Funding: This work was funded by the project "Achieving wider uptake of water-smart solutionsWIDER UPTAKE" (grant agreement number: 869283) financed by the European Union's Horizon 2020 Research and Innovation Programme, in which the first author of this paper, Giorgio Mannina, is the principal investigator for the University of Palermo. The Unipa project website can be found at: https:/ / wideruptake.unipa.it/ (accessed on 1 November 2021).

Institutional Review Board Statement: Not applicable.

Informed Consent Statement: Not applicable.

Data Availability Statement: Data sharing not applicable.

Conflicts of Interest: The authors declare no conflict of interest. 


\section{References}

1. Mannina, G.; Badalucco, L.; Barbara, L.; Cosenza, A.; di Trapani, D.; Gallo, G.; Laudicina, V.A.; Marino, G.; Muscarella, S.M.; Presti, D.; et al. Enhancing a transition to a circular economy in the water sector: The EU project wider uptake. Water 2021, 13, 946. [CrossRef]

2. $\quad$ Metcalf \& Eddy; Burton, F.L.; Stensel, H.D.; Tchobanoglous, G.I. Wastewater Engineering: Treatment and Reuse; McGraw-Hill Professional: New York, NY, USA, 2003.

3. Van Loosdrecht, M.C.M.; Brdjanovic, D. Anticipating the next century of wastewater treatment. Science 2014, 344, 1452-1453. [CrossRef]

4. $\quad$ Guest, J.S.; Skerlos, S.J.; Barnard, J.L.; Beck, M.B.; Daigger, G.T.; Hilger, H.; Jackson, S.J.; Karvazy, K.; Kelly, L.; Macpherson, L.; et al. A new planning and design paradigm to achieve sustainable resource recovery from wastewater. Environ. Sci. Technol. 2009, 43, 6126-6130. [CrossRef]

5. Puyol, D.; Batstone, D.J.; Hülsen, T.; Astals, S.; Peces, M.; Krömer, J.O. Resource recovery from wastewater by biological technologies: Opportunities, challenges, and prospects. Front. Microbiol. 2017, 7, 2106. [CrossRef] [PubMed]

6. Nielsen, P.H. Microbial biotechnology and circular economy in wastewater treatment. Microb. Biotechnol. 2017, 10, 1102-1105 [CrossRef]

7. Nizami, A.S.; Rehan, M.; Waqas, M.; Naqvi, M.; Ouda, O.K.M.; Shahzad, K.; Miandad, R.; Khan, M.Z.; Syamsiro, M.; Ismail, I.M.I.; et al. Waste biorefineries: Enabling circular economies in developing countries. Bioresour. Technol. 2017, 241, 1101-1117. [CrossRef] [PubMed]

8. Neczaj, E.; Grosser, A. Circular Economy in Wastewater Treatment Plant-Challenges and Barriers. Proceedings 2018, 2, 614. [CrossRef]

9. Kehrein, P.; van Loosdrecht, M.; Osseweijer, P.; Garfí, M.; Dewulf, J.; Posada, J. A critical review of resource recovery from municipal wastewater treatment plants-market supply potentials, technologies and bottlenecks. Environ. Sci. Water Res. Technol. 2020, 6, 877-910. [CrossRef]

10. Regmi, P.; Maere, T.; Stewart, H.; Amerlinck, Y.; Samstag, R.; Rieger, L.; Jimenez, J.; Johnson, B.; Vanrolleghem, P.A.; Takács, I.; et al. The future of WRRF modelling-Outlook and challenges. Water Sci. Technol. 2018, 79, 3-14. [CrossRef]

11. Pott, R.; Johnstone-Robertson, M.; Verster, B.; Rumjeet, S.; Nkadimeng, L.; Raper, T.; Rademeyer, S.; Harrison, S.T.L. Wastewater Biorefineries: Integrating Water Treatment and Value Recovery. In The Nexus: Energy, Environment and Climate Change. Green Energy and Technology; Leal Filho, W., Surroop, D., Eds.; Springer: Cham, Switzerland, 2018; pp. 289-302.

12. Verster, B.; Minnaar, S.; Cohen, B. Introducing the Wastewater Biorefinery Concept: A Scoping Study of Poly-Glutamic Acid Production from a Bacillus_-Rich Mixed Culture Using Municipal Wastewater; Water Research Commission Report TT587/13; Water Research Commission: Pretoria, South Africa, 2014.

13. Coats, E.R.; Wilson, P.I. Toward Nucleating the Concept of the Water Resource Recovery Facility (WRRF): Perspective from the Principal Actors. Environ. Sci. Technol. 2017, 51, 4158-4164. [CrossRef]

14. Daigger, G.T. Evolving Urban Water and Residuals Management Paradigms: Water Reclamation and Reuse, Decentralization, and Resource Recovery. Water Environ. Res. 2009, 81, 809-823. [CrossRef] [PubMed]

15. Bozkurt, H.; Gernaey, K.V.; Sin, G. Superstructure-Based Optimization Tool for Plant Design and Retrofitting. In Innovative Wastewater Treatment $\mathcal{E}$ Resource Recovery Technologies: Impacts on Energy, Economy and Environment; IWA Publishing: London, UK, 2017.

16. Peter, J.; der Hoek, V.; de Fooij, H.; Struker, A. Wastewater as a resource: Strategies to recover resources from Amsterdam's wastewater. Resour. Conserv. Recycl. 2016, 113, 53-64.

17. Alcalde Sanza, L.; Gawlik, B.M. Water Reuse in Europe: Relevant guidelines, needs for and barriers to innovation; JRC Science and Policy Report; Publications Office of the European Union: Luxembourg, 2014; pp. 1-18.

18. Karlikanovaite-Balikçi, A.; Yağci, N. A review on promising strategy to decrease sludge production: Oxic-Settling-Anoxic/anaerobic process. Environ. Res. Technol. 2020, 3, 81-91. [CrossRef]

19. Wang, K.; Zhou, Z.; Zheng, Y.; Jiang, J.; Huang, J.; Qiang, J.; An, Y.; Jiang, L.; Jiang, L.M.; Wang, Z. Understanding mechanisms of sludge in situ reduction in anaerobic side-stream reactor coupled membrane bioreactors packed with carriers at different filling fractions. Bioresour. Technol. 2020, 316, 123925. [CrossRef]

20. Lin, L.; Lei, Z.; Wang, L.; Liu, X.; Zhang, Y.; Wan, C.; Lee, D.J.; Tay, J.H. Adsorption mechanisms of high-levels of ammonium onto natural and NaCl-modified zeolites. Sep. Purif. Technol. 2013, 103, 15-20. [CrossRef]

21. Morgan-Sagastume, F.; Hjort, M.; Cirne, D.; Gérardin, F.; Lacroix, S.; Gaval, G.; Karabegovic, L.; Alexandersson, T.; Johansson, P.; Karlsson, A.; et al. Integrated production of polyhydroxyalkanoates (PHAs) with municipal wastewater and sludge treatment at pilot scale. Bioresour. Technol. 2015, 181, 78-89. [CrossRef]

22. Moretto, G.; Russo, I.; Bolzonella, D.; Pavan, P.; Majone, M.; Valentino, F. An urban biorefinery for food waste and biological sludge conversion into polyhydroxyalkanoates and biogas. Water Res. 2020, 170, 115371. [CrossRef]

23. Montiel-Jarillo, G.; Gea, T.; Artola, A.; Fuentes, J.; Carrera, J.; Suárez-Ojeda, M.E. Towards PHA Production from Wastes: The Bioconversion Potential of Different Activated Sludge and Food Industry Wastes into VFAs Through Acidogenic Fermentation. Waste Biomass Valorization 2021, 12, 6861-6873. [CrossRef]

24. Xin, X.; He, J.; Li, L.; Qiu, W. Enzymes catalyzing pre-hydrolysis facilitated the anaerobic fermentation of waste activated sludge with acidogenic and microbiological perspectives. Bioresour. Technol. 2018, 250, 69-78. [CrossRef] [PubMed] 
25. Nobaharan, K.; Novair, S.B.; Lajayer, B.A.; van Hullebusch, E.D. Phosphorus removal from wastewater: The potential use of biochar and the key controlling factors. Water 2021, 13, 517. [CrossRef]

26. Keinath, T.M. Operational Dynamics and Control of Secondary Clarifiers. J. Water Pollut. Control Fed. 1985, 57, 770-776.

27. Ekama, G.A.; Barnard, J.L.; Günthert, F.W. Secondary Settling Tanks: Theory, Modelling, Design and Operation; IWA Publishing: London, UK, 1997.

28. Grce, M.; Pavelić, K. Antiviral properties of clinoptilolite. Microporous Mesoporous Mater. 2005, 79, 165-169. [CrossRef]

29. Muscarella, S.M.; Badalucco, L.; Cano, B.; Laudicina, V.A.; Mannina, G. Ammonium adsorption, desorption and recovery by acid and alkaline treated zeolite. Bioresour. Technol. 2021, 341, 125812. [CrossRef]

30. Presti, D.; Cosenza, A.; Capri, F.C.; Gallo, G.; Alduina, R.; Mannina, G. Influence of volatile solids and pH for the production of volatile fatty acids: Batch fermentation tests using sewage sludge. Bioresour. Technol. 2021, 342, 125853. [CrossRef] [PubMed]

31. Takács, I.; Patry, G.G.; Nolasco, D. A dynamic model of the clarification-thickening process. Water Res. 1991, $25,1263-1271$. [CrossRef]

32. Soetardji, J.P.; Claudia, J.C.; Ju, Y.H.; Hriljac, J.A.; Chen, T.Y.; Soetaredjo, F.E.; Santoso, S.P.; Kurniawan, A.; Ismadji, S. Ammonia removal from water using sodium hydroxide modified zeolite mordenite. RSC Adv. 2015, 5, 83689-83699. [CrossRef]

33. Semmens, M.J.; Martin, W.P. The influence of pretreatment on the capacity and selectivity of clinoptilolite for metal ions. Water Res. 1988, 22, 537-542. [CrossRef]

34. Yuan, Q.; Sparling, R.; Oleszkiewicz, J.A. VFA generation from waste activated sludge: Effect of temperature and mixing. Chemosphere 2011, 82, 603-607. [CrossRef]

35. Mannina, G.; Alduina, R.; Badalucco, L.; Barbara, L.; Capri, F.C.; Cosenza, A.; Di Trapani, D.; Gallo, G.; Laudicina, V.A.; Muscarella, S.M.; et al. Water resource recovery facilities (Wrrfs): The case study of Palermo university (Italy). Water 2021, 13, 3413. [CrossRef]

36. Mannina, G.; Ekama, G.A.; Capodici, M.; Cosenza, A.; Di Trapani, D.; Ødegaard, H. Moving bed membrane bioreactors for carbon and nutrient removal: The effect of C/N variation. Biochem. Eng. J. 2017, 125, 31-40. [CrossRef]

37. Freni, G.; Mannina, G. Uncertainty in water quality modelling: The applicability of Variance Decomposition Approach. J. Hydrol. 2010, 394, 324-333. [CrossRef]

38. Istat. Previsioni Della Popolazione-Anni 2018-2065. Available online: http://dati.istat.it/Index.aspx?DataSetCode=DCIS_ PREVDEM1 (accessed on 6 October 2021).

39. Istat. Le Statistiche Dell'istat Sull'Acqua. Available online: https://www.istat.it/it/files/2020/03/Le-statistiche-Istat-sull \T1 $\backslash$ textquoterightacqua.pdf (accessed on 1 November 2021).

40. ISPRA. Qualità Delle Acque_Inquinamento da Pesticidi. Available online: https://annuario.isprambiente.it/sys_ind/report/ html/295\#C295 (accessed on 1 November 2021). 